TRADE POLICY AND WAGE GRADIENTS: EVIDENCE

FROM A

PROTECTIONIST TURN.

Daniel A. Tirado

Jordi Pons

Elisenda Paluzie

CSGR Working Paper 258/09

January 2009 
Trade policy and wage gradients: evidence from a protectionist turn.

Daniel A. Tirado

Universitat de Barcelona (Departament d'HistOria i Institucions EconOmiques)

Jordi Pons

Universitat de Barcelona (CAEPS)

Elisenda Paluzie

Universitat de Barcelona (Departament de Teoria EconOmica, CAEPS)

CSGR Working Paper 258/09

January 2009

Email: datirado@ub.edu

\begin{abstract}
:
In the spirit of Hanson (1997), we analyze the existence of regional nominal wage gradients in Spain during the interwar period (1914-1930) and their transformation following an important change in trade policy. However, our case study analyzes the effects of the substitution of an open economy by a closed one - exactly the reverse of the process studied by Hanson. We find strong evidence of the existence of a regional wage gradient centered on Barcelona, which weakened after 1922. In Spain during the interwar period protectionist policies appear to have favored the loss of centrality of the coastal location (Barcelona) and the relative rise of other locations.
\end{abstract}

Keywords: Trade Policy, Wage Gradient, Spain. 


\title{
Trade policy and wage gradients: evidence from a protectionist turn.
}

\author{
Daniel A. Tirado \\ Universitat de Barcelona (Departament d'Història i Institucions Econòmiques) \\ Jordi Pons \\ Universitat de Barcelona (CAEPS) \\ Elisenda Paluzie \\ Universitat de Barcelona (Departament de Teoria Econòmica, CAEPS)
}

January 2009

\begin{abstract}
In the spirit of Hanson (1997), we analyze the existence of regional nominal wage gradients in Spain during the interwar period (1914-1930) and their transformation following an important change in trade policy. However, our case study analyzes the effects of the substitution of an open economy by a closed one - exactly the reverse of the process studied by Hanson. We find strong evidence of the existence of a regional wage gradient centered on Barcelona, which weakened after 1922. In Spain during the interwar period protectionist policies appear to have favored the loss of centrality of the coastal location (Barcelona) and the relative rise of other locations.
\end{abstract}

\section{Introduction}

Recent decades have seen a revival of the interest in economic geography. Globalization and the appearance of regional blocks have contributed to this resurgence by intensifying the fear of radical changes in the localization of economic activities. The New Economic Geography has tried to explain which locations attract most firms and what are the mechanisms that make these locations attractive. ${ }^{1}$ One of these mechanisms is an externality demand, the market access effect, which predicts the concentration of economic activity in the regions with higher market potential. In this setting, trade liberalisation by changing the market potential of the regions, has an impact on the location of economic activities within countries. However, theorists have not yet reached a consensus on whether international trade liberalization increases the concentration of economic activities within a given country or whether gradual dispersion is observed as the country progressively opens up to trade (See Krugman

\footnotetext{
${ }^{1}$ See Fujita et al. (1999) for a formalization of the different possible agglomeration forces that give rise to industrial centers and Head and Mayer (2004) for a survey of the empirics of economic geography.
} 
and Livas, 1996; Monfort and Nicolini, 2000; Paluzie, 2001; Behrens et al., 2006; and Behrens et al., 2007 for a theoretical discussion on this issue). As for the location of industrial centers in a domestic market, and more particularly the location choice between border and interior regions, trade liberalization has two counteracting effects: increased market access (which is favorable to export production) and increased import competition (which is negative for domestic firms that compete with foreign producers). Depending on which of these two effects dominates, border regions will be favored or hampered by trade liberalization (See Crozet and Koenig-Soubeyran, 2004 and Brülhart, Crozet and Koenig, 2004).

In this paper we will contribute to solve this indeterminancy trough the analysis of the relationship between wages and market access across provinces in Spain. We will also test whether the different effects of trade policy on border and interior regions played an important role in the evolution of regional inequalities.

In the New Economic Geography models, such as Krugman (1991)'s seminal paper, an important prediction can be derived from the equilibrium condition of profit equalization between regions: that of the existence of regional wage inequalities. In Krugman's model, firms can afford to pay higher wages if they have good access to the larger market. The nominal wage in a region tends to be higher if incomes in other regions with low transport costs from this region are high. Hence, the wage equation in the model exhibits a kind of demand linkage or "backward linkage": in the regions with higher proportions of industry, wages are higher; this in turn attracts more workers, and so income and expenditure increase further in these regions. In equilibrium, differences in nominal wages persist between the different regions. Higher nominal wages act as a counterbalance to the better market access of central regions. They reflect the existence of agglomeration externalities.

Hanson (2005) pioneered a structural estimation of the wage equation present in the majority of economic geography models. ${ }^{2}$ However, non-structural methods can also be useful to analyze the relationship between market access and factor prices. For instance, a trade liberalization process may change the attractiveness of different locations inside a country as the importance of foreign markets to domestic producers rises. Border regions may be favored while central regions are hampered. Hanson (1997) uses trade liberalization in Mexico as a natural laboratory to test for these effects. For the period 1965-1988, he estimates a regional wage gradient, with nominal wages decreasing with transport costs from industrial centers. He shows that distance to industrial centers (Mexico City and the U.S.-Mexico border) has a negative influence on relative wages. Moreover, according to his hypothesis, the transition to

\footnotetext{
${ }^{2}$ Redding and Venables (2004) and Amiti and Cameron (2007) are other examples of this kind of structural approach to the consideration of wage inequalities.
} 
an open economy should lead to a compression of regional wage differentials and a weakening in the gradient to the capital as firms relocate from Mexico City to the U.S. border. The evidence for these expected changes is weaker. He finds no evidence of a structural break in the relationship between distance and relative regional wages following trade reform, or of a decrease in the effect of distance from the capital.

Can the Spanish experience in the interwar period provide new evidence in this respect? The second half of the 19th century was dominated by the rise of Barcelona (a province located in a region, Catalonia, bordering France) as the country's main center of industrial production. In those years, Barcelona came to concentrate a third of Spanish industrial output. However, the turn of the century marked a halt in this process as Madrid began to increase its share of Spanish manufacturing, gradually closing the gap vis-à-vis the Catalan city.

At that time, the reaction to the loss of Spain's remaining colonies put an end to the liberal regime which had been characterized by a relative trade openness, and implanted a protectionist model of development with harsh restrictions on the international trade of goods, semi-manufactures and raw materials. This protectionist turn was intensified in the interwar years with a further increase in tariffs in 1922.

In the spirit of Hanson (1997), we analyze the existence of regional nominal wage gradients in Spain during the interwar period (1914-1930) and their transformation following an important change in trade policy. However, our case study analyzes the effects of the substitution of an open economy by a closed one - exactly the reverse of the processes studied by Hanson. First, we find strong evidence for the existence of a regional wage gradient centered on Barcelona. Second, even though the trade shift we study is more gradual than the one analyzed by Hanson, we find strong evidence of the weakening of the gradient after the intensification of the protectionist turn in 1922.

The article is organized as follows. Section 2 presents the theoretical predictions for regional wages. Section 3 describes the evidence on the patterns of trade policy, industry location and regional wages in Spain. Section 4 presents our empirical analysis and discusses the results obtained. In the last section, we give the main conclusions and suggest some directions for further research. 


\section{Theoretical predictions}

\subsection{Industry agglomeration and regional wage gradients}

In the New Economic Geography, industrial agglomeration is presented as the result of demand and cost linkages between firms, created by the interaction between transport costs and fixed costs of production. One of these linkages, known as backward or demand linkage, forecasts that firms will be prepared to pay higher salaries in those regions that are closest to the main markets of consumption and production, since these regions enjoy lower transport costs. Hence, this demand linkage predicts the existence of regional wage gradients, with nominal wages decreasing with transport costs from industrial centers, and their possible reversal following changes in trade regimes.

To guide our analysis let us use the Spanish economy before WWI as an example. Which markets predominated in Spain at that time? Barcelona was the industrial center of the country, while the capital city of the country, Madrid, was an important source of demand. ${ }^{3}$ In contrast, external markets - that is, the former colonies and Europe- were never an important destination for Spanish industrial output. Altogether they absorbed less than $10 \%$ of Spanish total production. ${ }^{4}$ Nevertheless, foreign markets were important as a source of raw materials and intermediate goods required in the production of Barcelona's main industrial sectors, i.e. the consumer industries (textile and metallurgy).

The predictions of the model for regional relative wages can be summarized in the following reduced-form equation:

$$
\frac{w_{i}}{w_{c}}=F\left(x_{i}, x_{i}^{*}\right)
$$

where $w_{i}$ is the nominal wage in location $i, w_{c}$ is the nominal wage in the industry center (Barcelona), $x_{i}$ is unit transport costs from location $i$ to the industry center, and $x_{i}^{*}$ is unit transport cost from location $i$ to the capital city (Madrid). The function $F$ is conditional on location $c$ being the industry center.

It holds that

$$
w_{c} \geq w_{i}, i \neq c
$$

\footnotetext{
${ }^{3}$ In 1913, Madrid's industrial output relative to Barcelona was $40 \%$.

${ }^{4}$ In 1913, exports of manufacturing goods accounted for $25 \%$ of total exports. Considering that exports were less than $10 \%$ of GDP and that industrial output was around $25 \%$ of Spanish GDP, we can conclude that external markets absorbed less than $10 \%$ of Spanish industrial output.
} 


$$
\frac{\partial \frac{w_{i}}{w_{c}}}{\partial x_{i}}<0
$$

and,

$$
\frac{\partial \frac{w_{i}}{w_{c}}}{\partial x_{i}^{*}}<0
$$

Hence the hypothesis is that there is a regional wage gradient centered in Barcelona and that regional relative wages may also reflect transport costs to the capital city, Madrid. In this context, suppose there is a protectionist turn in trade policy. Trade protection reduces the attraction of the domestic industry center located at the border, Barcelona. To improve their access to the domestic market, firms may relocate to other central locations, in particular the capital city, Madrid. Nominal wages in Barcelona relative to nominal wages in other regions may be reduced. The transition to a closed economy causes a compression of regional wage differentials.

To test the existence of a regional wage gradient centered on Barcelona and its transformation following a change in trade regime, we specify the following reduced-form log-linear regression equation à la Hanson (1997):

$$
\log \left(\frac{w_{i t}}{w_{c t}}\right)=\beta_{o}+\beta_{1} \cdot \ln \left(x_{i t}\right)+\beta_{2} \cdot \ln \left(x_{i t}^{*}\right)+\mu_{i t}
$$

where $i$ indexes geographic location, $t$ indexes time, $c$ indexes the open-economy industry centre and $\mu_{i t}$ is an error term. Conditional on location $c$ being the industry center, the predictions are that (1) the regression coefficients $\beta_{1}$ and $\beta_{2}$ are negative, and (2) in the transition to a closed economy there is a structural break in this relationship, which reduces the effect of transport costs to the industry center, $\left|\beta_{1}\right|$, and increases the effect of transport costs to the capital city, $\left|\beta_{2}\right|$, on regional relative wages.

\subsection{Other sources of regional wage gradients}

Other sources of regional wage differentials such as the exogenous characteristics of regions, localized human capital spillovers or government policy have been analyzed extensively. ${ }^{5}$ Among the exogenous location specific characteristics, two stand out: regional differentials in resource endowments, and exogenous amenities. Firms may be driven to locate near natural resource concentrations. Regions endowed with minerals such as iron ore will attract industries that make intensive use of this resource. This in turn will attract firms in footloose

\footnotetext{
${ }^{5}$ See Hanson (2001) for a good survey of sources of regional wage differentials.
} 
industries in order to serve the market created by the agglomeration of the first type of industries. In these locations, firms will be able to pay higher wages to their workers. In contrast, exogenous amenities may lead to the opposite results for wages. For instance, workers may accept lower wages in regions endowed with good climate, beaches, and so on (See Roback, 1982). In principle, the effects of the exogenous characteristics of regions can be incorporated into equation (5) by including fixed location effects in the estimation.

As for localized human capital spillovers, the prediction is that regions with larger stocks of public knowledge will pay higher wages. (See Rauch, 1993 and Black and Henderson, 1999, for empirical tests on this issue).

Finally, government policy may also have an effect on regional wage patterns. If government activities concentrate in a particular region, they contribute to the creation of a consumption mass that will bid up regional wages.

\section{Trade policy and industrial location in Spain: The evidence}

During the second half of the 19th century and the first third of the 20th century, Spain's economic development, like that of most European countries, was dominated by the increase in the share of industry in production. The particularly hard road to industrialization was accompanied by an increasing domestic integration in markets of goods and factors that favored the productive specialization of Spanish regions.

Though domestic market integration goes back to the 18th century, it was not until the construction of the railway network during the second half of the 19th century that the effect of the reduction in internal transport costs led to real progress in market integration. The process was reinforced by the integration of the capital market with the unification of the monetary system (1869) and the expansion of the branches of the Central Bank, the Banco de España, after the Restoration of the Monarchy in 1874.

Finally, from 1869 onwards, this context of internal market integration was accompanied by a progressive economic openness towards neighboring countries (Tena, 1999). As Figure 1 shows, the reduction in tariff protection levels reached its maximum at the end of the 1880's, when Spain signed several trade treaties with its main trading partners. Further-

more, during the last decades of the 19th century, as O'Rourke and Williamson (1999) have recently highlighted, a considerable reduction in international transport costs due to technological innovations in maritime and land transport led to an increasing integration of national economies in the international markets, favoring international trade in goods and factors.

All this generated an upsurge in international trade. In fact, the rate of openness 
Figure 1: Nominal protection rates (\%). Spain, 1877-1926.

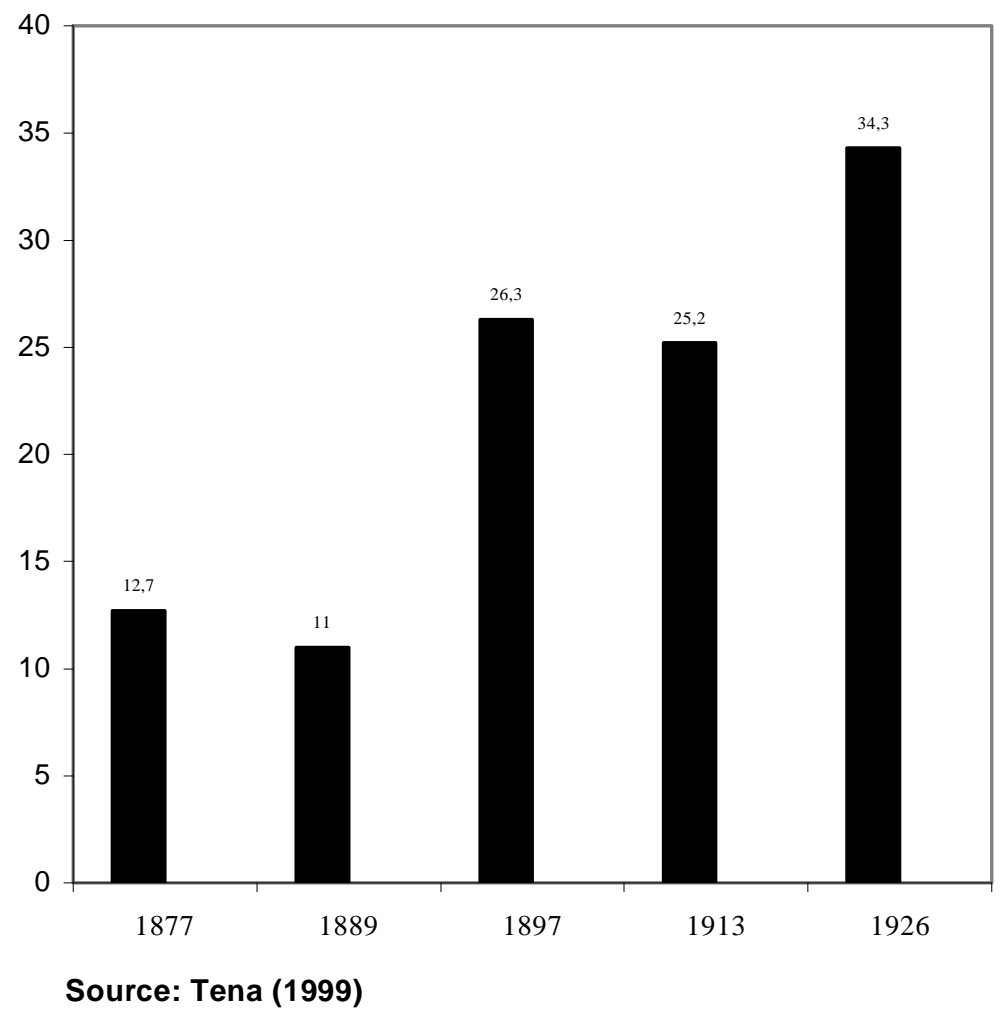

( $\frac{\text { exports + imports }}{\text { GDP }}$ Figure 2) reached by Spain at the beginning of the 1890's was not surpassed until the 1970's.

In these circumstances, the distribution of regional production in Spain underwent a profound transformation. In a descriptive analysis of the evolution of the geographical concentration of industries in Spain in the last 150 years, Paluzie et al. (2004) show that the largest increases in the levels of concentration are to be found during the long period between the middle of the 19th century and the Civil War (1936-1939). In this time, the geographical concentration of Spanish industry, as measured by the Gini index, increased substantially both at the aggregate level and in almost all the industrial sectors in which industrial production can be broken down.

With regard to the geographical localization of this increasingly concentrated manufacturing production, the phrase used by economic historians, that is, that Catalonia became Spain's factory, is highly appropriate. In Catalonia, during the second half of the 19th cen- 
tury, the rise in industrial production led to a considerable increase in the share of Catalan output in overall Spanish industrial production. In 30 years, Catalonia's contribution to Spanish industrial output rose from $25 \%$ to $40 \%$ (see Tirado et al., 2002).

Among Catalan regions, it was in the area around Barcelona, the historical capital, that most of this spectacular growth was found. Data coming from fiscal sources show that the coastal province of Barcelona, which had a long history of trade and manufacture, increased its share of Spanish industrial output from $18.56 \%$ in 1856 to $33 \%$ in $1893 .^{6}$

In Tirado et al. (2002), we concluded that Barcelona's rise as the main industrial center in Spain was linked to the existence of some initial comparative advantages which made the Catalan city a privileged location for the industrial processes characteristic of the first technological revolution. These initial advantages, in the presence of scale economies, favored the genesis of an industrial agglomeration around Barcelona on a scale much larger than that suggested by pure endowment considerations. All this took place in a context of relative openness.

But the last decade of the century saw an important change in terms of Spanish economy integration in the external markets. On the one hand, in 1883, the gold convertibility of the peseta was abandoned, thus debilitating Spain's position in the international capital markets. On the other, from 1892 on, the return to protectionism displayed in Figure 1 posed a serious threat to external integration. The results of this new turn in the tariff regime were soon noted. From 1895 onwards the rate of openness of the Spanish economy began to fall (Figure 2). In fact, these were the first signs of what has been called "the nationalistic road in Spanish capitalism": a policy that encouraged domestic production through protectionism and increasing public intervention to favor industrial production.

The most important expressions of this new model of development are to be found in the interwar years. At that time, the response to the crisis of overproduction caused by Spain's neutrality in WWI was a further increase in tariffs in order to protect Spanish industry (Cambó's tariff, 1922) and the implementation of infrastructure projects of investment which not only reinforced internal market integration but also increased demand for some domestic industrial sectors (Palafox, 1992).

\footnotetext{
${ }^{6}$ The variable used to compute these percentages is the quota paid by the province of Barcelona in the tax payments corresponding to the Contribución Industrial y de Comercio, Tarifa $3^{a}$ (Industrial and Commercial Contribution, third tariff). In this regard, we should note that Spanish total tax payments do not include the Basque Country and Navarre (these regions had their own fiscal system and were exempt from the payment of this tax). Hence, the indicator overestimates Barcelona's share in Spanish industrial output. This is not the case of the figures obtained in Tirado et al., 2002, calculated from estimates of Catalan and Spanish output. However, these estimates do not allow us to distinguish between the production of Barcelona and that of Catalonia as a whole. In any case, both indicators reflect a marked increase in the importance of Barcelona in the context of Spanish industry.
} 
Figure 2: Openness rates (\%). Spain, 1869-1935.

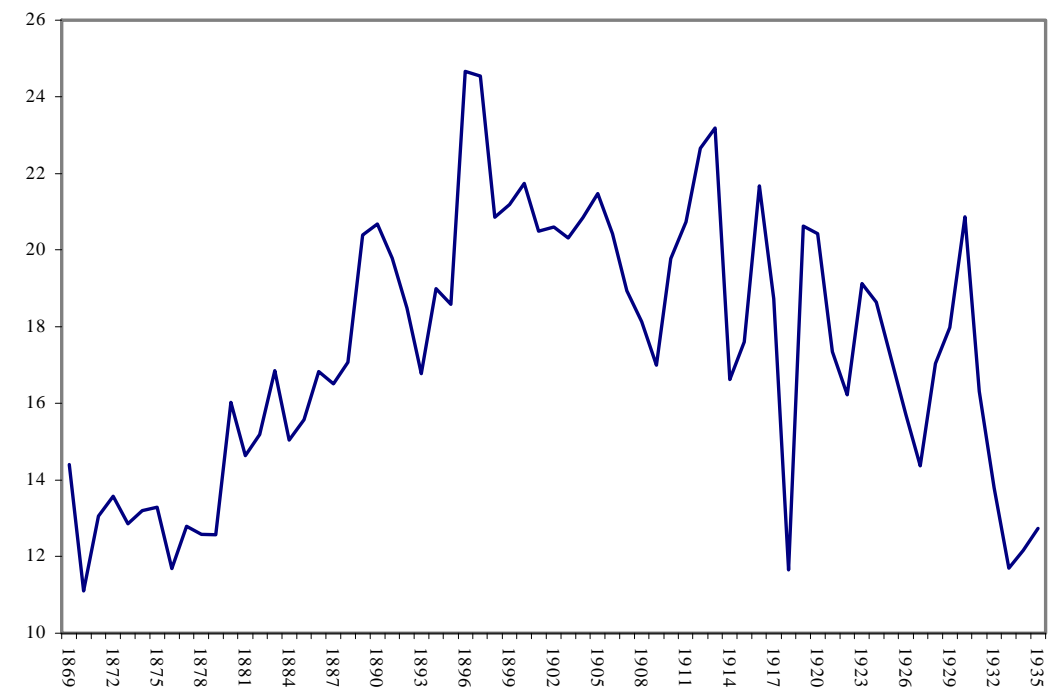

Source: Serrano Sanz (1997)

The policy change made Spain one of the most protectionist countries in the world. According to the League of Nations' report (1927), Spain's tariff levels were the highest in the world, followed at a short distance by those of the U.S. The Liepmann report (1938) ranks Spain second in protection in 1913 (after Poland) and third in 1927 and 1931 (after Poland and Bulgaria).

Table 1 reports Spanish protection levels in the period 1913-1931 from a comparative perspective. Two striking features emerge from these data. First, Spain's tariff levels were higher than those of other Western-European countries; second, only Germany showed a higher rate of growth in protection levels.

Table 1. Average ad-valorem tariffs (\%)

\begin{tabular}{|l|l|l|l|}
\hline & 1913 & 1925 & 1931 \\
\hline Spain & 37 & 44 & 68.5 \\
\hline Germany & 14.3 & 12 & 37.5 \\
\hline France & 18.8 & 12 & 29.6 \\
\hline Italy & 21.3 & 17 & 39.3 \\
\hline
\end{tabular}

Source. Liepmann (1938). The Liepmann report calculates nominal protection levels for 14 European countries on the basis of the tariffs levied on a sample of 144 export commodities. Each one of these products is important in the export structure of at least one of the considered countries. 
In addition to these extremely high tariffs, the importation of some intermediate goods and raw materials was prohibited. For instance, public consumption of foreign coal was impeded during the period 1907-1930, and private import consumption of coal was prohibited at several times after 1922. Not surprisingly, exports and imports fell drastically during this period and openness rates diminished considerably as a result.

What happened to location patterns after this change in trade policy? Agglomeration effects may be observed via regional differences in nominal wages or via differences in industrial concentration. We will take a look at the regional patterns of wages and at the regional distribution of industry.

To do this analysis we use nominal wage data for 47 Spanish provinces in 1914, 1920, 1925 and 1930 from the Estadística de Salarios y Jornadas de Trabajo published by the Ministry of Labor and Prevision (Ministerio de Trabajo y Previsión) in 1931 (henceforth, ESJT). This source gives provincial data on hourly wages for different worker categories computed from surveys. Data on industrial production for the years 1856, 1893, 1907, 1913 and 1929 is obtained indirectly through fiscal sources: the Contribución Industrial y de Comercio, a tax on firm's profits, published in the Estadística Administrativa de la Contribución Industrial y de Comercio and the Contribución de Utilidades, a tax on industrial corporations introduced in 1909, made available by Betrán (1995). ${ }^{7}$

Figures 3 and 4 plot the geographical distribution of the average nominal wage for manufacturing non-skilled workers in 1914 and 1930. In 1914, we observe a wage gradient centered on Barcelona in the Mediterranean axis (Catalonia, Valencia and Balearic Islands). By 1930, the Mediterranean wage gradient has considerably weakened. We also observe growth in the wages of other areas such as the north (Basque Country and Asturias) and the Ebro Valley (Aragon and Navarre).

As for the geographical location of industry, some important changes start to emerge. Although the geographical concentration of industries continued to rise at the aggregate level ${ }^{8}$ , there were changes in the location of the main industrial agglomerations. Catalonia's weight in Spanish industry, aside from some exceptional situations like WWI or the first years of the Second Republic, reached a standstill at the end of the 19th century. As for Barcelona, its weight in Spanish industry stabilized: in 1913, the province's contribution to Spanish industrial production was $27.63 \%$; in 1929 it was $28.55 \%$. Its relative growth had been remarkable

\footnotetext{
${ }^{7}$ In the absence of alternative data, fiscal sources have frequently been used by economic historians as a proxy for relative industrial output in Spanish regions.

${ }^{8}$ In Paluzie et al. (2004) we calculated the aggregate Gini index of geographical concentration of industries. It increased from a value of 0.68 in 1913 to 0.78 in 1929. This tendency was also verified at a higher level of disaggregation: five out of seven sectors increased their levels of concentration during those years.
} 
Figure 3: Nominal wages, non-skilled manufacturing workers, 1914

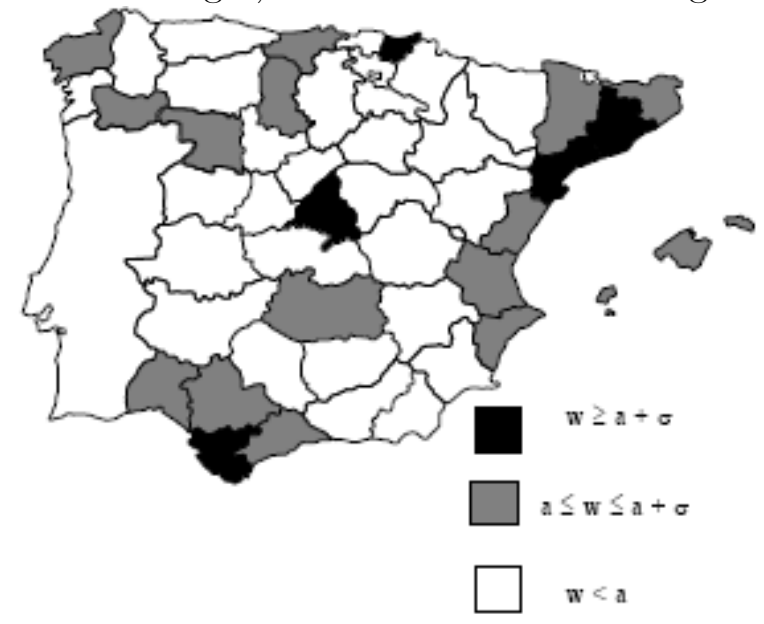

Figure 4: Nominal wages, non-skilled manufacturing workers, 1930

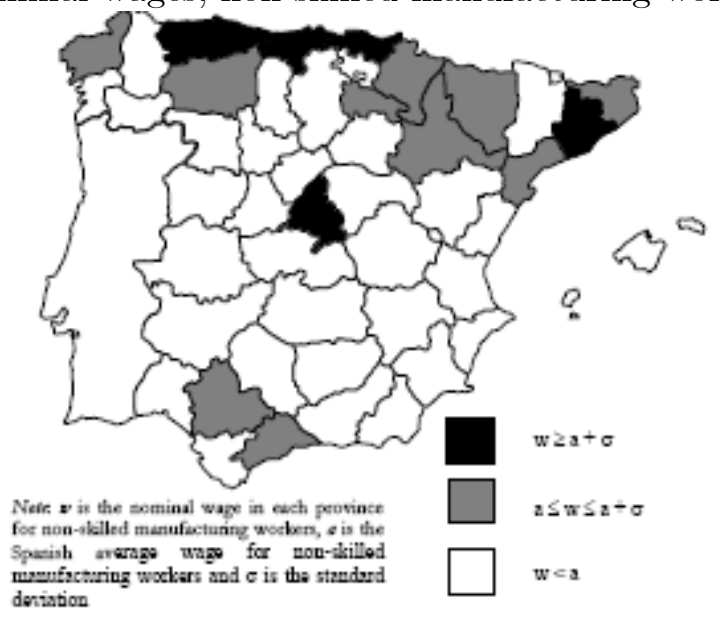

during the period 1856-1893, but now had come to an end. In contrast, a new group of territories began to move forward in Spanish industrial structure: the Basque provinces of Guipuzkoa and Biscay, Saragossa and Madrid, Spain's capital city and geographical center. (Betrán, 1999).

To obtain a more complete picture of the changes in industrial geography in the interwar period, we construct another index of industrial location: the industrial intensity index. This index is calculated as the ratio between the proportion of industrial activity in each territorial unit and the proportion of total population living there.

$$
\text { INTENS } S_{i}=\frac{\left(\frac{C_{i}}{\sum C_{i}}\right)}{\left(\frac{P O P_{i}}{\sum P O P_{i}}\right)}
$$


Figure 5: Madrid's industrial production vs. Barcelona's (\%)

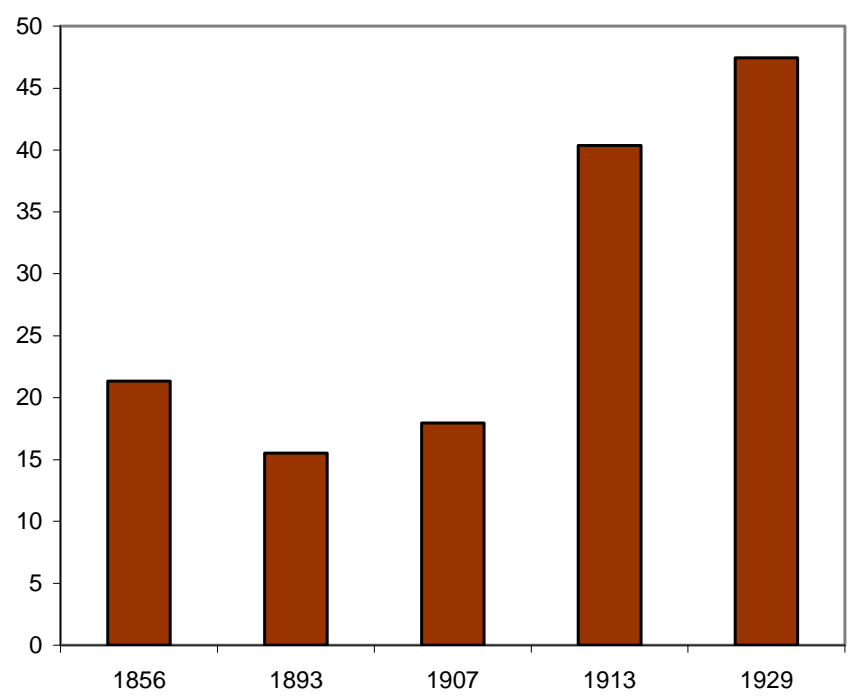

Source: own elaboration

where $C_{i}$ is the province's industrial production and $P O P_{i}$ is province $i$ 's total population. Hence, an index larger than one indicates that the province is specialized in industry, i.e., the relative weight of industrial activity is larger than that of the population. In contrast, an index of less than one indicates that the province is not specialized in industry.

The evolution of this index in the period 1856-1929 is interesting. First, the number of provinces that show industrial specialization fell considerably between 1856 and 1893, from 14 to 9; with the exception of Madrid and Seville, they all belong to the coastal periphery and 3 out of 4 Catalan provinces show industrial specialization. In 1913 there was a further reduction in the number of provinces specialized in industry (8) but now it was the Mediterranean periphery that lost importance to the benefit of Madrid and the Basque Country. ${ }^{9}$ Finally, in 1929, only seven provinces were specialized in industry. The periphery continued to decline; Barcelona was the only Catalan province still showing industrial specialization and Saragossa, a more central territory, presented industrial specialization for the first time.

Figure 5 plots the comparison between the industrial production of Madrid and Barcelona. During the second half of the 19th century, Madrid's

weight relative to Barcelona decreased from $22 \%$ to $15 \%$. The tendency started to change at the turn of the century. However, Madrid's most important advance occurred in the period

\footnotetext{
${ }^{9}$ We should note that no data are available to construct the INTENS index for the Basque Country and Navarre in 1856 and 1893.
} 
between WWI and the Great Depression. ${ }^{10}$

Both the pattern of regional wages and the regional shifts in industrial activity point towards a change in the market access forces that might have favored domestic centers of consumption such as Madrid and hampered locations closer to foreign markets such as Barcelona. In the empirical analysis, we will study the changes in the relative weights of industrial centres in Spain through the analysis of regional wage gradients and of their evolution following a trade policy change in the interwar years. The evolution of the regional wage gradient is a reduced form estimation of the market access forces at work.

\section{Empirical analysis}

For the empirical analysis we use nominal wage data for 47 Spanish provinces in 1914 and 1930 from the Estadística de Salarios y Jornadas de Trabajo published by the Ministry of Labor and Prevision (Ministerio de Trabajo y Prevision) in 1931 (henceforth, ESJT). This source gives provincial data on hourly wages for different worker categories computed from surveys. The level of aggregation is the average province wage in 8 manufacturing industries. We will use the wages of skilled manufacturing workers in 8 manufacturing sectors (Metallurgy, Chemistry, Textiles, Electricity, Apparel, Wood, Transports and Furniture), 4 time points (1914, 1920, 1925 and 1930) and a set of provinces which altogether represent 35\% of Spanish geography. From this information, we estimate the sectoral wage for the provinces for which we do not have direct data using the existing sectoral data and the data on the average provincial wage for skilled manufacturing workers, also given by the source. To measure transport costs, we use the distance by railway between provincial capitals in the period analyzed.

The functional form proposed in equation (5) will allow us to establish whether there was a wage gradient centered in Barcelona, and its possible changes following a shift in trade policy. ${ }^{11}$ The regression equation for this specification is:

\footnotetext{
${ }^{10}$ Figure 5 plots Madrid's relative weight compared with Barcelona in Spanish industrial output estimated from fiscal sources. Data for 1856, 1893 and 1907 are constructed from the Contribución Industrial y de Comercio, tarifa $3^{a}$. However, the data for 1913 and 1929 add a new tax, the Contribución de Utilidades, a compulsory new tax on industrial corporations introduced in 1909 (Betrán, 1995). Given this difference in the sources used we have to be cautious in the interpretation of the evolution between 1907 and 1913 . However, what we want to analyze in our paper is the beginning of a catching-up between Madrid and Barcelona from the end of the 19th century onwards. This tendency is maintained independently of the bond in levels caused by the change in the source.

${ }^{11}$ Upon demand we can provide the results of the estimation of equation (6) using only direct data. The results are not substantially different.
} 


$$
\begin{gathered}
\log \left(\frac{w_{i j t}}{w c j t}\right)=\beta_{o}+\beta_{1} \cdot \ln D_{i B C N}+\beta_{2} \cdot \ln D_{i M A D}+\theta_{0} \cdot f_{1920} \cdot \ln D_{i B C N}+\theta_{1} \cdot f_{1925} \cdot D_{i B C N} \\
+\theta_{2} \cdot f_{1930} \cdot \ln D_{i B C N}+\phi_{0} \cdot f_{1920} \cdot \ln D_{i M A D}+\phi_{1} \cdot f_{1925} \cdot \ln D_{i M A D} \\
+\phi_{2} \cdot f_{1930} \cdot \ln D_{i M A D}+\omega_{j t}+\varphi_{t}+\mu_{i j t}
\end{gathered}
$$

where $w_{i j t}$ is the nominal wage for sector $j$, in region $i$, at time t, $w_{c j t}$ is the central region (Barcelona) wage for sector $j$ at time $t, D_{i B C N}$ is distance from region $i$ to Barcelona, $D_{i M A D}$ is distance from region $i$ to Madrid, $f_{1920}, f_{1925}$ and $f_{1930}$ are year dummies, $\omega_{j t}$ is a time varying fixed effect for industry $j, \varphi_{t}$ is the fixed effect for year $t$, and $\mu_{i j t}$ is an i.i.d. term with mean zero and variance $\sigma .^{12}$

The theoretical predictions are that $\beta_{1}$ and $\beta_{2}$ are negative and that trade reform causes a change in the relationship between relative wages and transport costs. In particular, Barcelona's centrality should weaken over time. To test this second prediction, we interact the distance variables with time dummies so as to test for significant changes in the coefficients from year to year.

Table (2) gives estimation results. In all regressions we verify the existence of a wage gradient centered on the main industrial center, Barcelona. The estimated parameter of the variable $D_{B C N}$ is significant and negative. Its quantitative value indicates that a $10 \%$ increase in the distance to Barcelona leads to a reduction in the relative nominal wage of between 0.27 and $0.33 \%$. In column (b) we include both distance variables $D_{B C N}$ and $D_{M A D}$. As expected, distance to Barcelona is negative and significant. Distance to Madrid is positive and statistically significant at the $1 \%$ level. The results contradict the hypothesis that relative wages decline with distance to the capital city. However, for a majority of Spanish provinces (all those located in the South, Centre and West of the country) being close to Madrid implies being far from Barcelona. This fact could explain the positive sign of this coefficient.

In column (c) we interact distance to Barcelona with year dummies for 1920, 1925 and 1930. The estimated parameter on the interaction terms is positive and significant at $10 \%$ for the last two years of the period and, moreover, it increases over time. In contrast, in

\footnotetext{
${ }^{12}$ As more than $80 \%$ of Spanish Foreign Trade was carried by sea, we also estimated this equation including a time varying dummy for the existence of a seaport in the province. The estimated coefficient was not significant and we chose not to include this dummy in the regression. The reason for this result is the existence of provinces that have seaport but are far away from Barcelona, in the North-West of the Peninsula (Galice and Asturias). The effect of having a seaport is compensated by the effect of being very distant from the industrial centre.
} 
1920, it is not significant. This is evidence that the effect on wages of distance to Barcelona decreased suddenly after 1922 (the year of the Cambó tariff). Thus, we find evidence of a weakening in the wage gradient centered on Barcelona in that period. The estimated value of the coefficient on distance to this province is significantly larger in 1914 than in 1925 and 1930.

In column (d) we include both distance variables and we interact them with year dummies. Again the coefficient on the interaction term that includes distance to Barcelona is positive and significant at the $10 \%$ level for 1925 and 1930 but the interaction term with distance to Madrid is not significant for any of the three years considered. We thus reject the null hypothesis that the effect of distance on wages over time has remained the same only in the case of distance to Barcelona. There is strong evidence of a decrease in the effect of distance from Barcelona. Although not significant, the fact that the interaction term in the case of Madrid is negative while the coefficient on distance to Madrid is positive and significant points toward the hypothesis of a change in the wage gradient driven by rising wages in Madrid.

Table 2. Regression results for relative nominal wages by sectors

\begin{tabular}{|c|c|c|c|c|}
\hline Variables & (a) & (b) & (c) & (d) \\
\hline $\ln D_{B C N}$ & $\begin{array}{l}-0.031 \\
(0.000)\end{array}$ & $\begin{array}{l}-0.033 \\
(0.000)\end{array}$ & $\begin{array}{l}-0.027 \\
(0.009)\end{array}$ & $\begin{array}{l}-0.030 \\
(0.007)\end{array}$ \\
\hline $\ln D_{M A D}$ & & $\begin{array}{c}0.081 \\
(0.000)\end{array}$ & & $\begin{array}{c}0.081 \\
(0.000)\end{array}$ \\
\hline $\ln D_{B C N} \cdot f_{1920}$ & & & $\begin{array}{c}0.003 \\
(0.332)\end{array}$ & $\begin{array}{c}0.004 \\
(0.292)\end{array}$ \\
\hline $\ln D_{B C N} \cdot f_{1925}$ & & & $\begin{array}{c}0.008 \\
(0.091)\end{array}$ & $\begin{array}{c}0.010 \\
(0.087)\end{array}$ \\
\hline $\ln D_{B C N} \cdot f_{1930}$ & & & $\begin{array}{c}0.013 \\
(0.069)\end{array}$ & $\begin{array}{c}0.014 \\
(0.065)\end{array}$ \\
\hline $\ln D_{M A D} \cdot f_{1920}$ & & & & $\begin{array}{l}-0.006 \\
(0.592)\end{array}$ \\
\hline $\ln D_{M A D} \cdot f_{1925}$ & & & & $\begin{array}{l}-0.010 \\
(0.529)\end{array}$ \\
\hline $\ln D_{M A D} \cdot f_{1930}$ & & & & $\begin{array}{l}-0.012 \\
(0.449) \\
\end{array}$ \\
\hline Adjusted $\mathrm{R}^{2}$ & 0.450 & 0.491 & 0.458 & 0.497 \\
\hline $\mathrm{N}$ & 1472 & 1440 & 1472 & 1440 \\
\hline
\end{tabular}

level of significance for which we reject the null hypothesis of a parameter equal to zero. Standard errors are estimated by White's heteroskedasticity consistent method. In columns (a) and (d), we have $\mathrm{N}=1472$ observations because we consider 46 provinces (excluding Barcelona, the province of reference), 8 sectors and 4 time breaks. In columns (b) and (d), we have $\mathrm{N}=1440$ observations because we consider 45 provinces (excluding Madrid and Barcelona, the province of reference), 8 sectors and 4 time breaks. 
Overall our results give stronger support than Hanson (1997) for the hypothesis of a change in the regional wage structure following a shift in trade policy. We find evidence that the protectionist turn affected regional relative wages over the sample period. In particular, there was a weakening of the wage gradient centered on Barcelona.

To check the robustness of the regression results in relation to the regional fixed effects that could be captured by the error term in equation (6), we reestimate equation (6) replacing the distance variable with province dummy variables. With this regression, we want to analyze if the distance to the economic center is one of the elements to consider among the characteristics of each province that could explain the existence of wage differentials between them. The explanatory power of the model increases considerably (the adjusted $R^{2}$ increases to 0.794 ), indicating the existence of other specific characteristics of the provinces that matter for relative wages.

So, in order to test the importance of distance in explaining these specific characteristics of the regions, we regress the estimated province dummies on the distance vector. The results are as follows:

$$
\omega_{i}^{f e}=0.512-0.030 . \log D_{B C N}+0.089 \cdot \log D_{M A D}
$$

$R^{2} a d j=0.584$

$N=45$

where $\omega_{i}^{f e}$, is the estimated province effect for province $i$ and $D_{B C N}$ and $D_{M A D}$ are the distance variables. In brackets we indicate the significance level for which we reject the null hypothesis of a parameter equal to zero. We verify that the distance variables explain a high percentage $(58.4 \%)$ of the variance in fixed province effects, thus suggesting that transport costs, as measured by distance, are an important factor among the characteristics of the provinces that explain the geographical structure of relative nominal wages.

Overall, the empirical analysis supports the hypothesis of the existence of a wage gradient, centered on the province of Barcelona, explained by the existence of transport costs to Barcelona. However, as mentioned in Section 2, other hypotheses may yield the same prediction for regional relative wages: 1) exogenous natural resource supplies, 2) exogenous levels of amenities, 3) human capital stocks, and 4) location bias in government policy.

For exogenous natural resource supplies to yield the same main prediction of equation (6), i.e the existence of a gradient centered on Barcelona, it must be true that this region concentrates natural resources. This was not the case; Barcelona lacked natural resources such as water, minerals or coal. For the exogenous levels of amenities to yield the same 
predictions as equation (6) it must be true that they increase with distance from Barcelona and Madrid. The evidence suggests the opposite is in fact the case. Moreover, we also believe that amenities were not an important factor in the location decision of firms during the first stages of industrialization. As for human capital stocks, in particular, regional levels of education indicate that Catalonia's position was only average, and that this position did not vary during the period considered. (Catalonia's literacy rate was seventh out of 15 NUTS2 regions in Spain in both 1900 and 1930). Finally, for location bias in goverment policy to lead to the same predictions as equation (6), it must be true that government activities were concentrated in Barcelona or that Barcelona benefited from public subsidies. In fact, most of government activities were concentrated in the capital city, Madrid, throughout our sample period.

As for the hypothesis of a weakening of the wage gradient, we find significant evidence in the second half of the period 1914-1930. Both the Cambó tariff in 1922 and the restriction on imports of cheap coal after this date could explain the reduction of the effect of distance to Barcelona on regional wages. Although the shift in trade policy was gradual and had begun by the end of the 19th century, the centrality of Barcelona was only clearly reduced after these two strict measures were imposed.

However, in addition to the trade policy shift, this result could also be explained by a comparative advantage in natural resources. In fact, these explanations are not mutually exclusive, but complementary. On the one hand, the changes in the comparative advantage of the regions in this period are inextricably linked to the change in trade policy. It was the prohibition on the importing of coal and the high tariff protection imposed on steel production that gave a comparative advantage to northern regions such as Asturias and the Basque Country and disadvantaged a region, Catalonia, which lacked natural resources, and saw its centrality reduced.

Other possible explanations for the change in the wage gradient such as changes in the demand from abroad or changes in trade policy of the main trading partners can be ruled out in the Spanish case. As we highlighted in Section 2, external markets were never an important source of demand for Spanish industrial products. As for possible changes in the trade policy of the main trading partners, the fact that Spanish exports did not fall in the period 1913-1929 suggests that there were no relevant changes in this area. 


\section{Conclusions}

This paper has proved the existence of a gradient in the geographical structure of nominal wages in Spain in the interwar period centered on the main manufacturing cluster, Barcelona. We have also confirmed a weakening in this gradient over time. The abandonment of a liberal trade policy at the end of the 19th century and especially during the interwar period, weakened Barcelona's role and enhanced the relative growth of other locations.

As far as the theoretical debate is concerned, the Spanish case in the first industrialization wave illustrates the effects of the closing of an economy to international trade, precisely the reverse of the trade policy change recently analyzed by the literature. The new scenario did not imply a reduction in the geographical concentration of production, as measured by the Gini indices. However, the most important changes that occurred during this period were in the location of the main industrial agglomerations. The new trade regime weakened the role of the coastal region, Barcelona, which had concentrated an increasing share of Spanish industrial output during the period of greatest opening to foreign trade; we thus provide support for Crozet and Koenig-Soubeyran (2004)'s hypothesis on the effects of trade policy changes when one of the regions has a pronounced advantage in access to international markets. The evidence we found of a structural break in the relationship between distance and relative wages after trade reform is stronger than Hanson (1997).

In addition, this paper brings new insights into Madrid's rise as an important industrial center on Spain. Historians have pointed to some irrefutable facts, such as its status as the capital-city and the main communications hub. Yet they have not been able to explain why the relative rise of Madrid began precisely at the turn of the century, and not before or afterwards. In this article we have suggested a possible explanation, though as yet the evidence found is not conclusive. The progressive closing of the Spanish economy tended to weaken the privileged position of the coastal regions and favor the rise of the central regions. If we consider this change in the trade policy regime, we can explain the precise chronology of Madrid's relative rise.

In future research, we aim to test our hypothesis further, by analyzing the recent experience of a trade liberalization reform in Spain in the second half of the 20th century.

If the theoretical predictions that we tested in this paper still hold, Barcelona's centrality should be re-established. 


\section{A Appendix. Descriptive analysis of wage data}

Table A1. Descriptive statistics of wages

\begin{tabular}{|c|c|c|c|c|c|}
\hline & & $\mathbf{1 9 1 4}$ & $\mathbf{1 9 2 0}$ & $\mathbf{1 9 2 5}$ & $\mathbf{1 9 3 0}$ \\
\hline Metallurgy & Mean & 0.504 & 0.956 & 1.085 & 1.125 \\
\hline & Std. Dev. & 0.055 & 0.206 & 0.182 & 0.158 \\
\hline Chemistry & Mean & 0.440 & 0.812 & 0.946 & 0.979 \\
\hline & Std. Dev. & 0.094 & 0.205 & 0.194 & 0.190 \\
\hline Textiles & Mean & 0.450 & 0.762 & 0.895 & 0.893 \\
\hline & Std. Dev. & 0.125 & 0.170 & 0.184 & 0.183 \\
\hline Electricity & Mean & 0.451 & 0.868 & 1.025 & 1.085 \\
\hline & Std. Dev. & 0.077 & 0.193 & 0.210 & 0.193 \\
\hline Apparel & Mean & 0.442 & 0.809 & 0.937 & 0.969 \\
\hline & Std. Dev. & 0.070 & 0.194 & 0.161 & 0.152 \\
\hline Wood & Mean & 0.520 & 1.003 & 1.122 & 1.084 \\
\hline & Std. Dev. & 0.085 & 0.262 & 0.169 & 0.208 \\
\hline Transports & Mean & 0.537 & 0.965 & 1.099 & 1.083 \\
\hline & Std. Dev. & 0.069 & 0.246 & 0.142 & 0.199 \\
\hline Furniture & Mean & 0.517 & 1.002 & 1.145 & 1.141 \\
\hline & Std. Dev. & 0.115 & 0.144 & 0.183 & 0.176 \\
\hline INDUSTRY & Mean & 0.437 & 0.769 & 0.927 & 0.937 \\
\hline & Std. Dev. & 0.056 & 0.153 & 0.146 & 0.140 \\
\hline
\end{tabular}

Source: ESJT

Note: the unit of measure is pesetas/hour. Data by sectors come from the wages of skilled workers, while average data (industry) are from the wages of non-skilled workers.

\section{References}

[1] Amiti, M. and Cameron, L. (2007) "Economic geography and wages", The Review of Economics and Statistics, vol 89, 15-29.

[2] Behrens, K. (2004): "International integration and regional inequalities: how important is national infrastructure?", CORE discussion paper 2004/66, Université Catholique de Louvain.

[3] Behrens, K., C. Gaigné, G. Ottaviano, and J-F. Thisse (2006) "Is remoteness a locational disadvantage?, Journal of Economic Geography, 6, 347-368.

[4] Behrens, K., C. Gaigné, G. Ottaviano, and J-F. Thisse (2007 "Countries, regions and trade: On the welfare impacts of economic integration", European Economic Review, 51, $1277-1301$. 
[5] Betrán, C. (1999) "Difusión y localización industrial en España durante el primer tercio del siglo XX", Revista de Historia Económica, 3, 663-696.

[6] Black, D. and Henderson, V. (1999) "A theory of urban growth", Journal of Political Economy, 107, 252-284.

[7] Brülhart M., Crozet, M. and Koenig-Soubeyran, P. (2004) "Enlargement and the EU periphery: The impact of Changing Market Potential", World Economy, 27(6), 853-875.

[8] Crozet, M. and Koenig-Soubeyran, P. (2004) "EU enlargement and the internal geography of countries", Journal of Comparative Economics, 32, 265-279.

[9] Fujita, M., Krugman, P. and Venables, A. J. (1999) The Spatial Economy: Cities, Regions and International Trade. The MIT Press, Cambridge.

[10] Hanson, G. H. (1997) "Increasing returns, trade and the regional structure of wages", Economic Journal, 107, 113-133.

[11] Hanson, G. H. (2001) "Scale economies and the geographic concentration of industry", Journal of Economic Geography, 1, 255-276.

[12] Hanson, G. H. (2005) "Market potential, increasing returns, and geographic concentration", Journal of International Economics, 67, 1-24.

[13] Head, K. and Mayer, T. (2004) "The empirics of agglomeration and trade", in Henderson, V. and Thisse, J. (eds.), Handbook of Regional and Urban Economics, NorthHolland.

[14] Krugman, P. (1991) "Increasing returns and economic geography", Journal of Political Economy, 99, 483-499.

[15] Krugman, P. and Livas Elizondo, R. (1996) "Trade policy and third world metropolis", Journal of Development Economics, 49, 137-150.

[16] League of Nations (1927) Tariff Level Indices. Publications of the League of Nations, Economic and Financial Section, Geneva.

[17] Liepmann, H. (1938) Tariff levels and the economic unity of Europe. George Allen \& Unwin, Edinburgh.

[18] Monfort, P. and Nicolini, R. (2000) "Regional convergence and international integration", Journal of Urban Economics, 48, 286-306. 
[19] O’Rourke, K.H. and Williamson, J. G. (1999) Globalization and History: The evolution of Nineteenth-century Atlantic Economy, Cambridge, MIT Press

[20] Palafox, J. (1992) Atraso económico y democracia. La Segunda República y la economía española (1892-1936), Barcelona, Crítica.

[21] Paluzie, E. (2001) "Trade policy and regional inequalities", Papers in Regional Science, $80,67-85$.

[22] Paluzie, E. , Pons, J. and Tirado, D. A. (2004) "The geographical concentration of industry across Spanish Regions, 1856-1995", Jahrbuch für Regionalwissenschaft (Review of Regional Research), 24 (2), 143-160.

[23] Rauch, J. E. (1993) "Productivity gains from geographic concentration of human capital: evidence from the cities", Journal of Urban Economics, 34, 380-400.

[24] Redding, S. and Venables, A.J. (2004) "Economic geography and international inequality", Journal of International Economics, 62, 53-82.

[25] Roback, J. (1982) "Wages, rents, and the quality of life", Journal of Political Economy, 90, 1257-1278.

[26] Serrano Sanz, J. M. (1997) "Sector exterior y desarrollo en la economía española contemporánea", Papeles de Economía Española, 73, 308-335.

[27] Silvestre, J. (2005) "Internal migrations in Spain, 1877-1930", European Review of Economic History, 9, 233-265.

[28] Tena, A. (1999) "Un nuevo perfil del proteccionismo español durante la Restauración, 1875-1930", Revista de Historia Económica, 3, 579-622.

[29] Tirado, D. A., Paluzie, E. and Pons, J. (2002) "Economic Integration and Industrial Location: the case of Spain before World War I", Journal of Economic Geography, 2, 343-363. 


\section{$\underline{\text { CSGR Working Paper Series }}$}

226/07 May

227/07 May

228/07 May

229/07 June

230/07 June

231/07 June

232/07 July

233/07 July

234/07 September

235/07 October

236/07 November

237/08 March

238/08 March

239/08 March

241/08 March

242/08 January
Dan Bulley

Exteriorising Terror: Inside/Outside the Failing State on 7 July 2005

Kenneth Amaeshi

Who Matters to UK and German Firms? Modelling Stakeholder Salience

Through Corporate Social Reports

Olufemi O. Amao and Kenneth M. Amaeshi

Galvanising Shareholder Activism: A Prerequisite for Effective Corporate

Governance and Accountability in Nigeria

Stephen J. Redding, Daniel M. Sturm and Nikolaus Wolf History and Industry Location: Evidence from German Airports

Dilip K. Das

Shifting Paradigm of Regional Integration in Asia

Max-Stephan Schulze and Nikolaus Wolf

On the Origins of Border Effects: Insights from the Habsburg Customs Union

Elena Meschi and Marco Vivarelli

Trade Openness and Income Inequality in Developing Countries

Julie Gilson

Structuring Accountability: Non-Governmental Participation in the Asia-Europe Meeting (ASEM)

Christian Thimann, Christian Just and Raymond Ritter

The Governance of the IMF: How a Dual Board Structure Could Raise the

Effectiveness and Legitimacy of a Key Global Institution

Peter I. Hajnal

Can Civil Society Influence G8 Accountability?

Ton Bührs

Towards a Global Political-Economic Architecture of Environmental Space

Kerstin Martens

Civil Society, Accountability And The UN System.

Diane Stone

Transnational Philanthropy, Policy Transfer Networks and the Open Society Institute.

Dilip K. Das

The Chinese Economy: Making A Global Niche

Dwijen Rangnekar

Geneva rhetoric, national reality: Implementing TRIPS obligations in Kenya.

Priscillia E. Hunt

Heterogeneity in the Wage Impacts of Immigrants. 


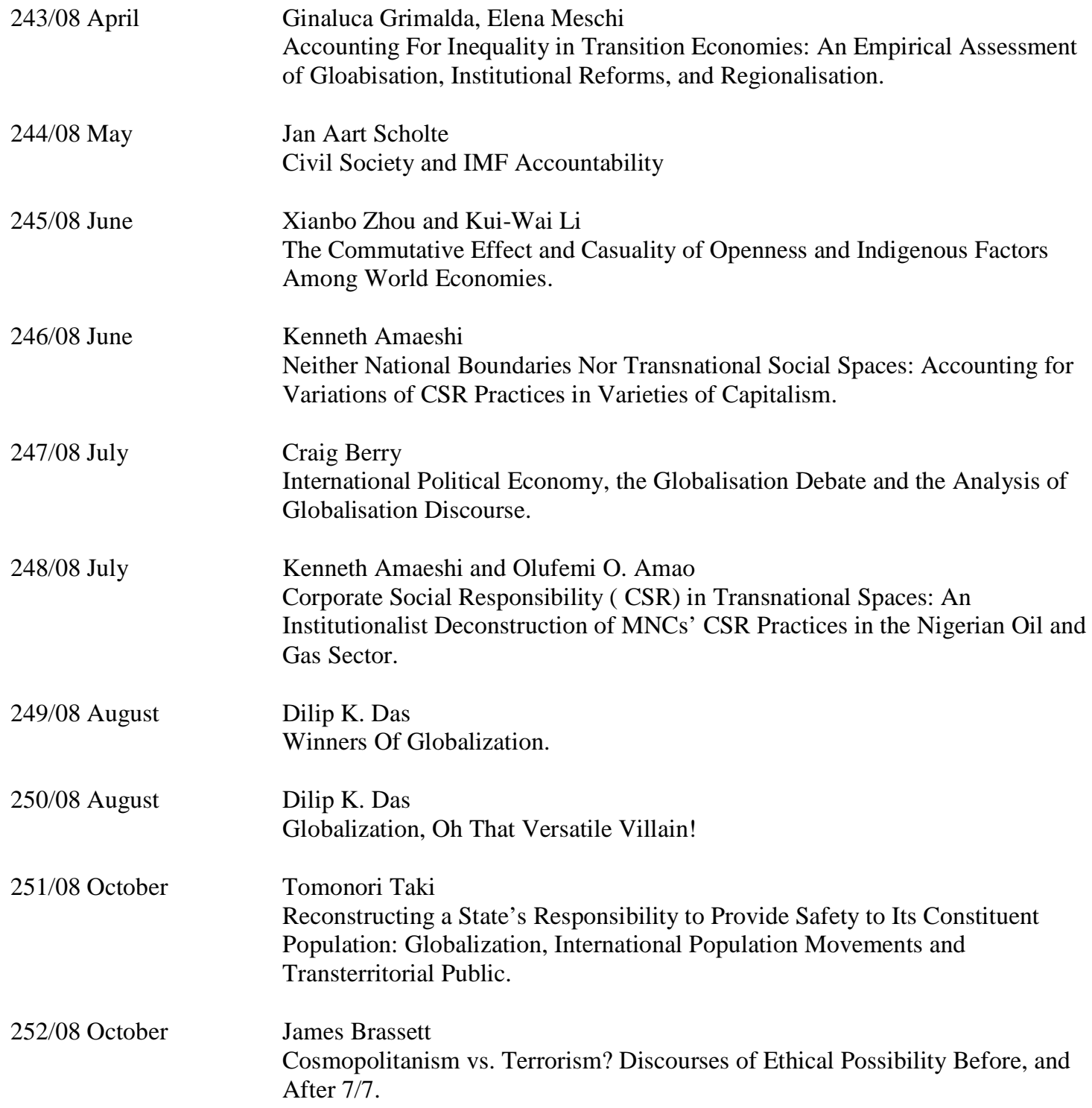

\section{Centre for the Study of Globalisation and Regionalisation}

University of Warwick

Coventry CV4 7AL, UK

Tel: $+44(0) 2476572533$

Fax: +44 (0)247657 2548

Email: csgr@warwick.ac.uk

Web address: http://www.csgr.org 